International Journal of Engineering \& Technology, 9(1)(2020) 84-91
International Journal of Engineering \& Technology
SPC
Website www.sciencepubco.com/index.php/IJET
Research paper

\title{
Effect of gypsum content on unsaturated engineering properties of clayey soil
}

\author{
Mohammed N J Alzaidy* \\ Assistant lecturer, Civil Engineering Department, University of Mosul, Nineveh, Iraq \\ *Corresponding author E-mail: mohammednawaf@uomosul.edu.iq
}

\begin{abstract}
Many of gypsum soils have existed in arid and semi-arid lands. It is considered one of the most problematic soils because of its complicated and unpredicted behavior when exposure to moisture. Extensive researches have been conducted in Iraq to observe the behavior of such soil and to suggest safety restrictions for the collapse and set practical precautions for the structures. This study investigated the effect of gypsum content on some unsaturated engineering properties of a clayey soil. Three different proportions of gypsum ( $0 \%, 5 \%$ and $20 \%$ by weight of the parent soil) were added and tested. The samples have been subjected to swelling potential test, soil water retention curve (SWRC), vapour diffusion and shear strength parameters. It is observed that gypsum content has a significant influence on SWRC, whereas, soil that has high gypsum content made SWRC with higher variables represented by air entry values and residual state. On the other hand, an increase in gypsum content led to a reduction of swelling potential and shear strength parameters. The results of vapour diffusion indicate that gypsum content could modify the microstructure in an unsaturated state and reduce the vapour diffusion through the soil.
\end{abstract}

Keywords: Gypseous Soil; Shear Strength; Swelling Potential; Unsaturated Soil; Vapour Diffusion.

\section{Introduction}

Gypsum soils make a challenge problem to the geotechnical engineers due to their dangerous behavior. Any building constructed on a gypsum soil might experience unpredictable deformations which might cause damaged failure. In Iraq noticed that many buildings have exhibited various patterns of cracks and differential deformations which are primarily due to the exposure of the gypsum soils to moisture. It is recognized that gypsum soils exhibit a quite low compressibility and high bearing capacity when the dry state is dominant. On the other hand, an unexpected collapsible behavior will observed when exposed to moisture led to dissolution of various kinds of salts existed in the mass of gypsum soil will make new pores through the soil particles and release the cementitious bonds between the soil skeletons. This progression makes an unstable structure which facilitates the particles sliding into a high dense status. The rate of gypsum dissolution depends mainly on the environmental effects in water content due to the fluctuation of ground water table or surface water, climate conditions represented by permeability, flow characteristics and temperature, as well as gypsum content and its type Al-Saoudi and Al-Khafaji $[1]$.

Assessment the unsaturated engineering properties for soil in a wide range of gypsum content considered an essential matter in several geoenvironmental and geotechnical applications like embankments, pavement layers, engineering liners and covers Vanapalli, Fredlund, Pufahl et al., [2].

The engineering behavior of unsaturated soils can be better interpreted when the suction effect takes in consideration Fredlund [3]. Suction is playing an important role in recognizing the unsaturated properties of the soil like shear strength, unsaturated permeability and water vapour, deformation, and volume change properties. Recently, suction analysis in the situation of the previous geotechnical engineering properties has become the matter of many researchers in the branch of unsaturated soil mechanics Sheng, Zhou, and Fredlund [4].

The soil water retention curve (SWRC) represents the relationship between the soil suction and the corresponding moisture content of the soil. The moisture content can be represented in different forms which are volumetric, gravimetric water content and degree of saturation Fredlund and Rahardjo [5]; Fredlund and Rahardjo [6]. The SWRC considered a measure of the water holding or storage capacity of the soil due to the change of moisture content when subjected to different values of suction. SWRC is a conceptual and interpretative tool enables to understand the behavior of unsaturated soils. When the soil changes from saturation to dry state (unsaturation process), the soil moisture and air phase distribution will change, however, the stress state will change. The relationships between the previous phases take on various patterns and effect on the engineering properties of unsaturated soils.

Many factors influence the SWRC like type of soil, texture, structure, mineralogy and plasticity Nam Gutierrez, Diplas et al., [7] compaction characteristics which represent moisture content, dry density and compaction effort Vanapalli, Pufahl, Fredlund [8] stress history, void ratio, heat, suction measurement processes...etc. Vanapalli, Fredlund, Pufahl [9]. Soil specimens which have the same texture and mineralogy, can have slight differences in SWRC shape and its variables, so, engineering behavior of each specimen will also differs. 
The objective of this research article is to observe experimentally the effect of gypsum proportions added to a clayey soil on:

- Swelling potential behavior,

- Soil water retention curve shape and variables,

- Water vapour diffusion through soil skeleton, and

- Saturated and unsaturated shear strength parameters using a predicted model.

\section{Materials and experimental methods}

\subsection{Materials}

Two materials have been employed in this research for specimen preparation: silty clay soil and commercial gypsum powder. The soil specimen used in this study is a fine grained soil, which has been obtained from east of Mosul city, the axes were specified as $\left(36^{\circ} 18^{\prime} 01.8^{\prime \prime} \mathrm{N}, 42^{\circ} 13^{\prime} 41.5^{\prime \prime} \mathrm{E}\right)$, at depth varied between (2.0-3.0) $\mathrm{m}$ under the ground level. Thereafter, the sample were homogenized and placed in polyethylene bags and transferred to the geotechnical laboratory. Index properties like Atterberg limits, specific gravity, hydrometer analyses and compaction characteristics tests have been carried out. Table 1 presented some of indices and engineering properties of the studied soil, using the desired tests in accordance with ASTM specifications [10]. Depending on Casagrande plasticity chart and the Unified Soil Classification System, the soil has been classified as clay with low to medium plasticity (CL).

Gypsum powder is a mineral salt consists of Hydrated Calcium Sulphate $\left(\mathrm{CaSO}_{4} 2 \mathrm{H}_{2} \mathrm{O}\right)$. The gypsum used in this research have been obtained from the Merck KGaA company-Germany, which is a fine material and passes through $80 \mu \mathrm{m}$ sieve, and the purity ratio not less than $99 \%$.

Table 1: Index and Physical Properties of Soil

\begin{tabular}{lll}
\hline Properties & & \\
\hline Liquid Limit (\%) & & \\
Plastic Limit (\%) & 28.1 \\
Plasticity Index (\%) & 14.4 \\
pH & 7.90 \\
Specific Gravity & 2.65 \\
Sand (\%) & 6 \\
Silt (\%) & \\
Clay (\%) & \\
Natural Gypsum Content (\%) & \\
Standard Compaction Characteristics & Optimum Moisture Content $(\%)$ \\
& Maximum Dry Unit Weight $\left(\mathrm{kN} / \mathrm{m}^{3}\right)$ \\
Saturated shear strength parameters & Cohesion, c' (kPa) \\
Soil Classification (USCS) & Friction angle, $\varphi^{\prime}\left({ }^{\circ}\right)$ \\
\hline
\end{tabular}

\subsection{Specimens preparation}

In order to demonstrate the effect of gypsum content on some unsaturated engineering properties of a clayey soil, the preparation of all specimens was done in the laboratory. A procedure was followed on soil specimens having different contents of gypsum $(0 \%, 5 \%$ and $20 \%$ of dry soil weight), in order to obtain homogeny of the specimens, soil passed through \#4 (4.75 mm) sieve have been used.

The preparation of soil specimens consists of: drying the soil materials in an oven at $60^{\circ} \mathrm{C}$ for 2 days, then, mixed the specific amount of soil with the desired gypsum content under dry conditions. The desired water content chosen in this research represents the optimum moisture contents related to maximum dry density obtained from the standard compaction tests according to ASTM D-698 [10] as shown in Table 1. Proper care should be taken in consideration when mixing to obtain homogeneous mixture. The soil specimens have been stored in polyethylene bags for 24 hrs. before compaction for moisture homogeneity. Thereafter, the soil specimens have been statically compacted according to maximum dry density of the studying soil. The dimensions of soil specimens used for SWRC were $50 \mathrm{~mm}$ in diameter and $10 \mathrm{~mm}$ in height. The specimens of SWRC were developed by statically compacted soil specimens, while, the specimens used for swelling potential, water vapour diffusion and shear strength tests have been retrieved by trimming from the mould of standard compaction characteristics.

\subsection{Determination of free swell potential}

A swelling potential test have been carried out on soil specimens having different gypsum content using standard one dimensional oedometer in accordance with ASTM D-4546 [10]. The soil samples have been put into the cell of the apparatus between double dried porous stones. A sensitive dial gauge was installed on top of the specimen for vertical displacement measurement. The vertical displacement measurement precision and axial strain were $0.001 \mathrm{~mm}$ and $0.005 \%$ respectively, in accordance with ASTM D-6026 [10].

\subsection{Determination of soil water retention curve}

SWRC can be computed by direct or indirect techniques which induce suction of soil. The first technique measures the negative pore water pressure directly corresponding to suction. While the second technique needs to other parameters to measure like moisture content, relative humidity, thereafter; relate the suction results during calibration. In this research, two techniques have been employed to compute the suction for the entire range $\left(10-10^{6}\right) \mathrm{kPa}$, consist of: techniques of osmotic membrane and water vapour equilibrium.

SWRC for the suction range (100-1500) kPa have been computed with osmotic membrane technique. The soil specimens were installed in a semi permeable membrane, thereafter, the latest will submerged in a polyethylene glycol solution having various concentrations to impose various suction values. Proper contact is necessary between the membrane and soil specimens. Duration of 30 days is required for the equilibrium soil specimens to get. 
SWRC at high suction ranges were computed with the vapour equilibrium technique, where the relative humidity (RH) at the airspace over the salt solution depends on the concentration and chemical composition of the related solution as shown in Table 2 . By selecting a proper chemical solution with a specific relative humidity, soil specimens inside the desiccator will absorbs or desorbs moisture vapour from airspace until equilibrium is reached. Duration of 7 weeks is required for the equilibrium soil specimens to get, as shown in Fig. 1. The two previous techniques have been conducted at control room temperature $20^{\circ} \mathrm{C}$.

Total suction can be determined using Kelvin's equation when the relative humidity of the airspace is given as below Aldaood, Bouasker, Al-Mukhtar [11]:

$$
\psi(\mathrm{kPa})=-\frac{\mathrm{R} . \mathrm{T}}{\mathrm{V}} \ln [\mathrm{RH}]
$$

Where:

$\psi=$ Total suction,

$\mathrm{R}=$ Universal gas constant,

$\mathrm{T}=$ Absolute temp., and

$\mathrm{V}=$ Specific volume of water at specified temp

Table 2: Chemical Solutions Used in Vapour Equilibrium Technique

\begin{tabular}{llcc}
\hline No & Chemical composition & Relative humidity (RH) \% & Average suction (kPa) \\
\hline 1 & $\mathrm{LiCl}$ & 11 & 288,570 \\
2 & $\mathrm{Ca}\left(\mathrm{NO}_{3}\right)_{2} \cdot 4 \mathrm{H}_{2} \mathrm{O}$ & 44 & 81,300 \\
3 & $\mathrm{NaCl}$ & 76 & 37,350 \\
4 & $\mathrm{KCl}$ & 86 & 20,500 \\
5 & $\mathrm{CuSO}_{4} \cdot 5 \mathrm{H}_{2} \mathrm{O}$ & 98 & 2,750 \\
\hline
\end{tabular}

(A)

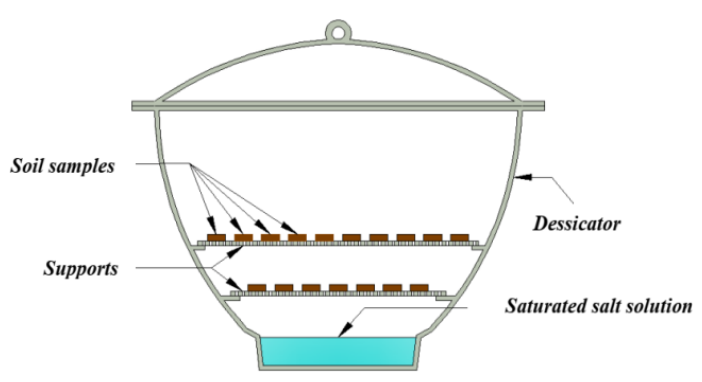

(B)

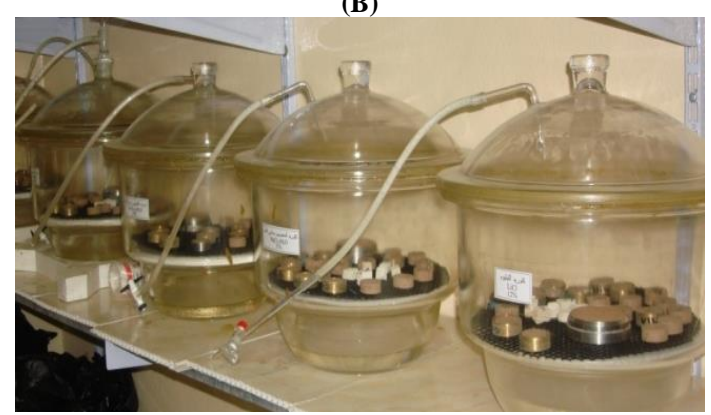

Fig. 1: Vapour Equilibrium Technique, A) Schematic Diagram, B) Desiccators, Khattab and Alzaidy [12].

Fredlund \& Xing, Fredlund and Rahardjo [6] demonstrated that the air entry value (AEV) defined as the suction where air starts to enter into the largest pores existing between soil particles. The residual moisture content $(\theta r)$ is the moisture content which high suction range is required to decrease additional moisture. SWRC parameters represented by air entry and residual state could be calculated by drawing a three tangent lines; the first one at the initial point of the curve, the second one at the inflection point of the curve, and the last one at the point where the curve seems to reduce linearly at high suction range. SWRC parameters can be concluded from the intersections of these tangent lines as exhibited in Fig. 2.

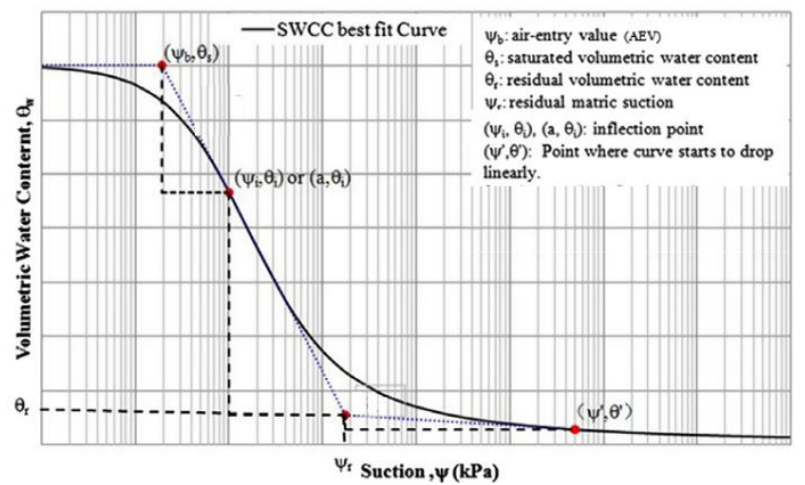

Fig. 2: Soil Water Retention Curve Variables, Zhai and Rahardjo [13].

\subsection{Determination of vapour diffusion}

Measurements of vapour diffusion have been conducted with the apparatus shown in Fig. 3. It is consisted of two cells containing various relative humidity due to the saturated salt solution at each one. Soil specimens (with $63.5 \mathrm{~mm}$ in diameter and $19 \mathrm{~mm}$ in height) were placed in the middle of the apparatus between the two cells, the pans of saturated salt solutions have been weighed rapidly and installed immediately in the cell. The vapour diffusion is transferred due to the suction differences between the two cells, the left cell which has higher relative humidity to right one which has lower relative humidity. The water gain is measured with time. The right pan of the cells was weighed every 48 hrs every two weeks, thereafter, twice a week until the equilibrium reach which is approximately 8 week Beck AlMukhtar, Rozenbaumb et al., [14]. This procedure is carried out with four diffusion apparatus with various saturated salt solutions (various suction gradients). 
(A)

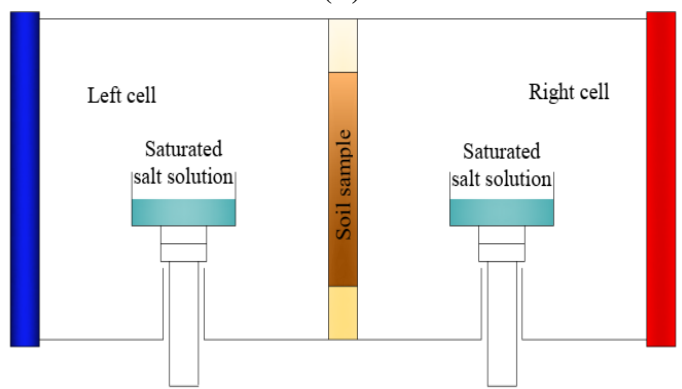

(B)

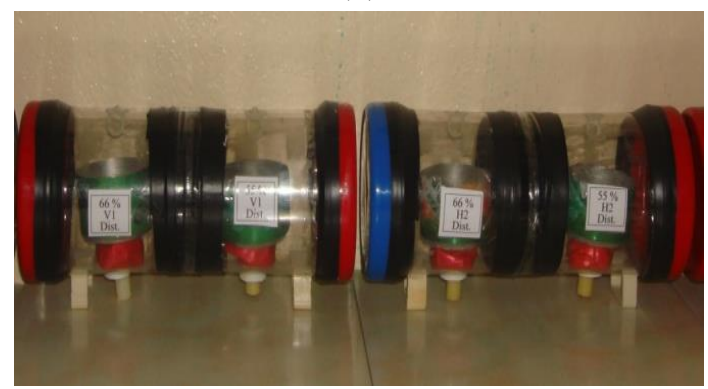

Fig. 3: Vapour Diffusion Apparatus, A) Schematic Diagram, B) Apparatus, Khattab and Alzaidy [12].

Vapour transfer occurs due to the suction gradient between the two cells, the coefficient of diffusion depends on the volumetric moisture content of the specimen. The transfer is conduct through the specimen thickness related to suction differences imposed at the left and right of the specimen. Hence, the general flow equation used in such problem Beck Al-Mukhtar, Rozenbaumb et al., [14] is:

$\frac{\partial \psi}{\partial \mathrm{t}}=\mathrm{D}(\theta) \frac{\partial^{2} \psi}{\partial \mathrm{x}^{2}}$

Where:

$\mathrm{x}=$ Water transfer distance,

$\mathrm{t}=$ Required time for water transfer,

$\psi=$ Total suction, and

$\mathrm{D}(\theta)=$ Water vapour diffusivity.

\subsection{Determination of unsaturated shear strength parameters}

Mohr-Coulomb failure criterion and the effective stress concept are usually used to describe the shear strength of a saturated soil. For unsaturated soil it is defined as an extended Mohr Coulomb failure envelope, where it can be considered as an extension for the saturated shear strength equation, which is as follows Fredlund, Morgernstern, Widger [15]:

$\tau_{\mathrm{ff}}=\mathrm{c}^{\prime}+\left(\sigma_{\mathrm{f}}-\mathrm{u}_{\mathrm{a}}\right)_{\mathrm{f}} \tan \varphi^{\prime}+\left(\mathrm{u}_{\mathrm{a}}-\mathrm{u}_{\mathrm{w}}\right) \tan \varphi^{\mathrm{b}}$

Where:

$\tau_{\mathrm{ff}}:$ Shear stress at failure,

$c^{\prime}$ : Intercept of the extended Mohr Coulomb failure envelope with shear stress axis,

$\left(\sigma_{\mathrm{f}}-\mathrm{u}_{\mathrm{a}}\right)_{\mathrm{f}}:$ Net normal stress at failure,

$\mathrm{u}_{\mathrm{af}}$ : Pore air pressure,

$\varphi^{\prime}:$ Internal friction angle,

$\left(\mathrm{u}_{\mathrm{a}}-\mathrm{u}_{\mathrm{w}}\right)_{\mathrm{f}}$ : Matric suction at failure, and

$\varphi^{\mathrm{b}}$ : Angle indicating the increasing rate in shear strength relative to matric suction.

Mohr Coulomb circles at failure criteria for unsaturated soils are drawn with three dimensional axes, as exhibited in Fig. 4. The y-axis axis is the shear stress, $\tau$, the $\mathrm{x}$-axis is $\left(\sigma_{\mathrm{f}}-\mathrm{u}_{\mathrm{a}}\right)$, and the $\mathrm{z}$-axis is $\left(\mathrm{u}_{\mathrm{a}}-\mathrm{u}_{\mathrm{w}}\right)$ which are the stresses variables. The plane tangent to Mohr Coulomb circles at failure is described as the extended Mohr Coulomb failure envelope of unsaturated soil which describes the unsaturated shear strength of soil. The intersection line between the $x-y$ plane and the extended Mohr Coulomb failure envelope is considered the saturated failure envelope, whereas at the intersection with $x-y$ plane the matric suction is zero.

The unsaturated shear strength of soil can be computed with customized direct shear or triaxial tests. Researches corresponding to the computation of the unsaturated shear strength consider cost and time consuming and require extensive laboratory facilities to conduct Gan, Fredlund, and Rahardjio [16]. Recently, many semi empirical procedures were proposed in order to predict the unsaturated shear strength of soil Vanapalli, Fredlund, Pufahl et al., [2]. They depend on SWRC variables and saturated shear strength parameters to perform.

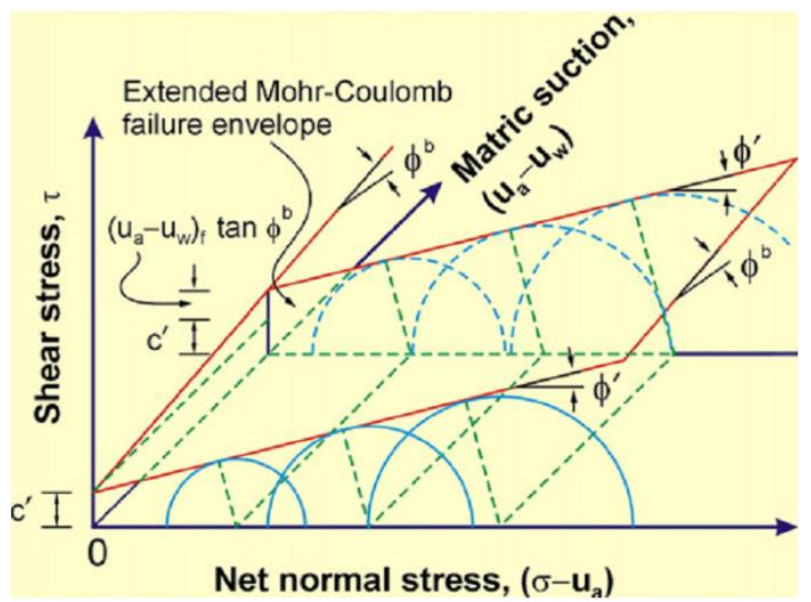

Fig. 4: Extended Mohr's Coulomb Failure Envelope of Unsaturated Soil, Fredlund et al., [17]. 
Vanapalli and others Vanapalli, Fredlund, Pufahl et al., [2] were proposed a general nonlinear equation for the unsaturated shear strength prediction with full suction range of SWRC $(0-1,000,000) \mathrm{kPa}$, and the saturated shear strength variables as shown:

$\tau_{\mathrm{ff}}=\left[\mathrm{c}^{\prime}+\left(\sigma_{\mathrm{f}}-\mathrm{u}_{\mathrm{a}}\right) \tan \varphi^{\prime}\right]+\left[\left(\mathrm{u}_{\mathrm{a}}-\mathrm{u}_{\mathrm{w}}\right) \Theta \tan \varphi^{\prime}\right]$

Where:

$\Theta$ : Normalized water content, $\frac{\theta-\theta_{\mathrm{r}}}{\theta_{\mathrm{s}}-\theta_{\mathrm{r}}}$

The shear strength contribution due to suction consists on the second term of the equation: $\tau_{u_{s}}=\left[\left(u_{a^{-}} u_{w}\right) \Theta \tan \varphi\right.$ ']. Equation (4) can be also expressed in forms of gravimetric moisture content or degree of saturation, giving similar results.

\section{Results and discussion}

\subsection{Swelling potential test}

The effect of gypsum content on swelling potential of clayey soil samples are plotted in Fig. 5. It is noticed that with an increase in gypsum content, there is a notable decrease in swell potential and the variation curve showed a distinct reduce initially. The swelling potential values are given in Table 3. The value is reduced from $2.65 \%$ at $0 \%$ gypsum content (Natural soil) to be $1.9 \%$ at $5 \%$ gypsum content, thereafter, swelling potential values reduced in a gentle slope to reach $0.8 \%$ at $20 \%$ gypsum content. This drop in the swelling potential value is due to the role of gypsum content which is play as a cementitious material that binds the adjacent soil particles each other.

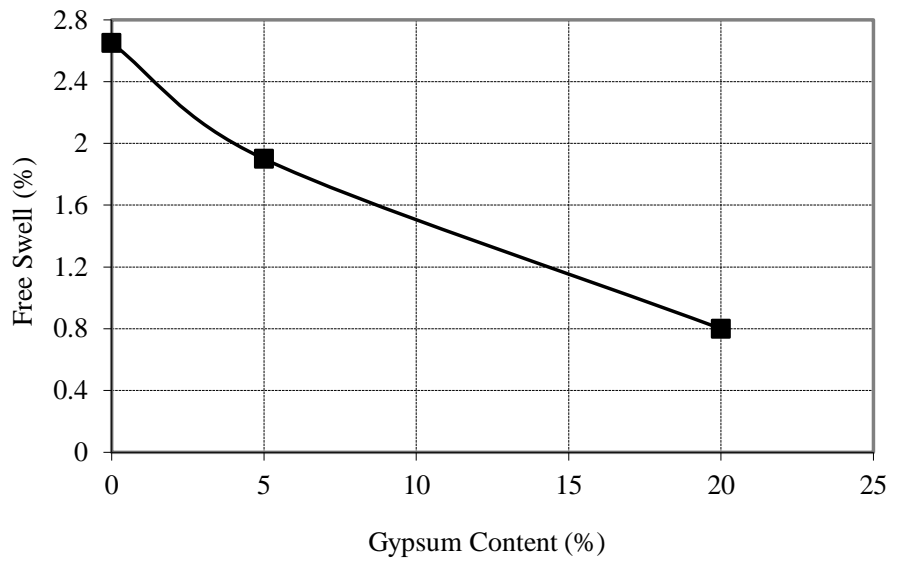

Fig. 5: Effect of Gypsum Content on Swelling Potential Value.

Table 3: Swelling Potential and Shear Strength Parameters

\begin{tabular}{lcccc}
\hline \multirow{2}{*}{ No. } & \multirow{2}{*}{ Gypsum content $(\%)$} & Swelling potential $(\%)$ & \multicolumn{2}{c}{ Saturated shear strength parameters } \\
\cline { 3 - 5 } & 0 & 2.65 & 35.4 & 28.8 \\
2 & 5 & 1.90 & 25.1 & 25.8 \\
3 & 20 & 0.80 & 20.0 & 23.8 \\
\hline
\end{tabular}

\subsection{Soil water retention curve}

SWRC of soil specimens compacted at standard compactive effort is plotted in Fig. 6 in term of volumetric water content with soil suction. It can be seen that the increasing in gypsum content led to increase in water content. The water storage behavior can be divided into three parts due to the suction value:

- At higher suction values (more than $100,000 \mathrm{kPa}$ ) the moisture contents obtained for different gypsum content are practically equivalent.

- At suction values $(2700-100,000) \mathrm{kPa}$, a little higher moisture content can be noticed for specimens having higher gypsum content.

- At suction values less than $2700 \mathrm{kPa}$, the variations of moisture content seems to begin with high to lower variation and continues until saturation occurs. The variation in the moisture contents of specimens having various gypsum contents seems to be a steady for suctions under $200 \mathrm{kPa}$. 


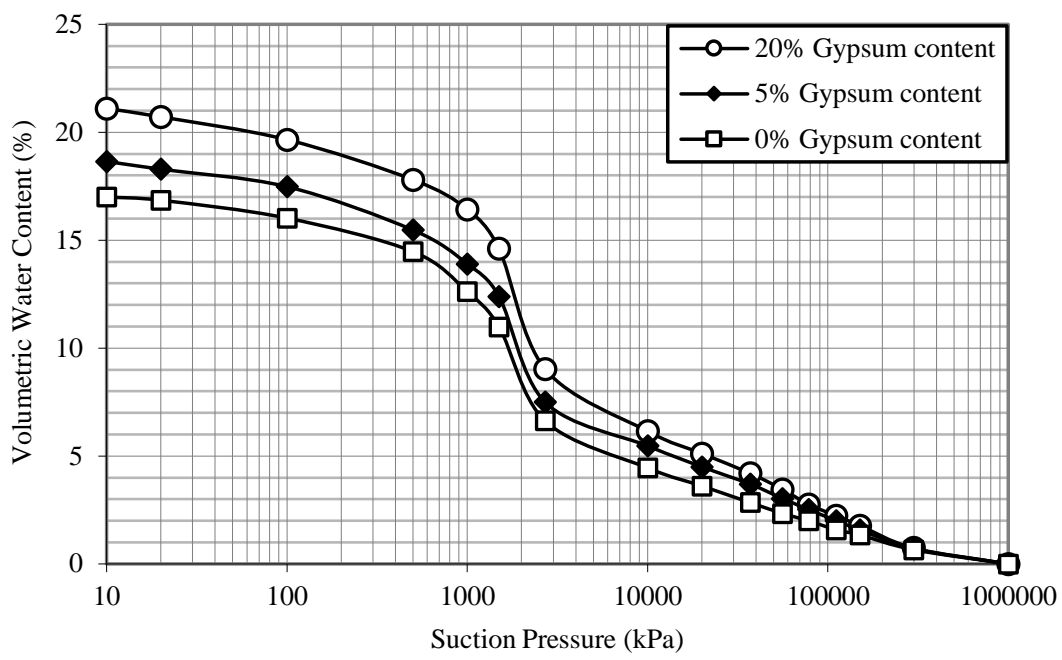

Fig. 6: Effect of Gypsum Content on SWRC.

Table 4 exhibits the SWRC variables consisted of (Air entry and residual states and their suctions) for 0\%, 5\% and 20\% gypsum content, the $0 \%$ gypsum content has high interconnected pores and exhibits a trend to vary in volumetric moisture content with a relative high rate due to increase in suction, whereas the variety is decreased with increasing gypsum content. It seems that the air entry and the saturation residual state trend to be high for soil having high gypsum content.

Table 4: Soil Water Retention Curve Variables

\begin{tabular}{|c|c|c|c|}
\hline \multirow{2}{*}{ Variable } & \multicolumn{3}{|c|}{ Values } \\
\hline & 0\% gypsum & $5 \%$ gypsum & $20 \%$ gypsum \\
\hline Air entry value $(\mathrm{AEV}), \psi_{\mathrm{b}}(\mathrm{kPa})$ & 850 & 1000 & 1050 \\
\hline Saturated volumetric water content, $\theta_{\mathrm{s}}$ & 15.2 & 16.5 & 19.0 \\
\hline Residual suction, $\psi_{\mathrm{r}}(\mathrm{kPa})$ & 2550 & 2700 & 2800 \\
\hline Residual volumetric water content, $\theta_{\mathrm{r}}$ & 6.2 & 7.6 & 8.4 \\
\hline
\end{tabular}

\subsection{Water vapour diffusion results}

The effect of gypsum content on the vapour diffusion with time at different suction gradient values (Different relative humidity at the two sides of the soil specimens) is plotted in Fig. 7. Also, Table 5 exhibited the maximum vapour diffusion weight gains at right cell through the soil specimen. It is observed from figure that the vapour diffusion values increased non linearly for all specimens, and this increasing is decreased with time until equilibrium is reached. This increasing is relative with the suction gradient, whereas, the values of vapour weight gain are increased with increasing suction gradient. This behavior can be attributed to the quick transfer and accessibility of the water vapour through the porous phase due to the large difference in the relative humidity existing at the two sides of the soil specimen. It is noticed that gypsum content has a significant influence on vapour diffusivity, whereas, the values is decreased with increasing gypsum content, and this relative differences is more evident at low suction gradient than that at high suction gradient. This is can be attributed to the role of gypsum particles which are very fine materials led to clog the pore spaces existing between soil particles and formation of cementitious minerals causing reduce the water vapour diffusion through the porous phase.

Table 5: Maximum Vapour Diffusion Weight Gains

\begin{tabular}{|c|c|c|c|c|c|}
\hline \multirow{2}{*}{ No. } & \multirow{2}{*}{ Gypsum content $(\%)$} & \multicolumn{4}{|c|}{ Relative humidity for the two cells (\%) } \\
\hline & & $11-44$ & 44-76 & 76-86 & 86-98 \\
\hline 1 & 0 & 9.5 & 8.6 & 3.7 & 3.3 \\
\hline 2 & 5 & 8.6 & 8.0 & 3.3 & 2.9 \\
\hline 3 & 20 & 7.6 & 6.7 & 2.5 & 2.0 \\
\hline
\end{tabular}
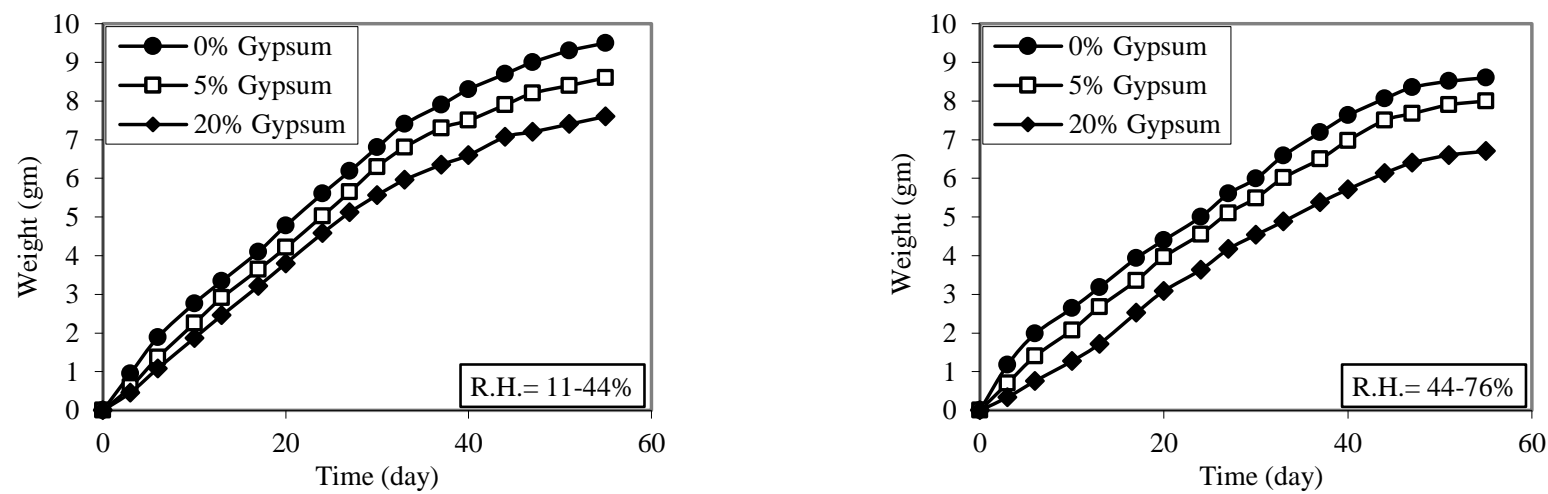

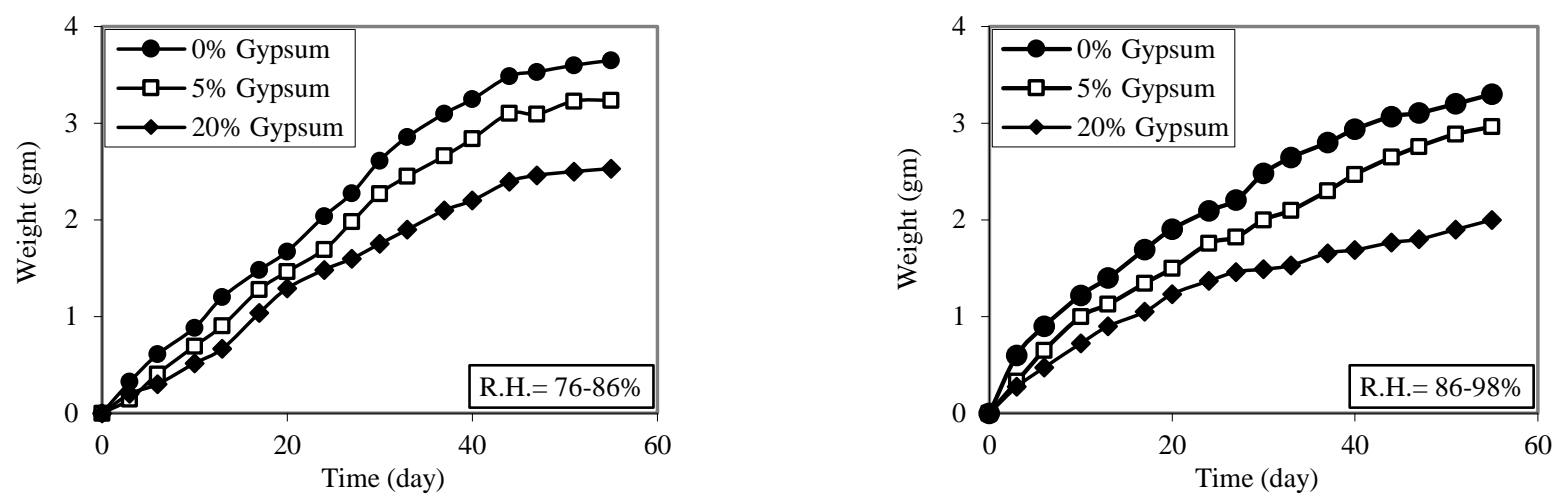

Fig. 7: Vapour Diffusion versus Time of Soil Specimens with Different Gypsum Content and Suction Gradients.

\subsection{Shear strength parameters}

\subsubsection{Shear strength envelopes of saturated soil}

Direct shear test was carried out according to ASTM specifications [10], to compute the shear strength parameters (c', $\left.\varphi^{\prime}\right)$ of the clayey soil having different percentages of gypsum content. A consolidated undrained conditions (cu-test) were conducted on specimens with dimensions $(60 \times 60 \times 20) \mathrm{mm}$, the rate of strain is $0.02 \mathrm{~mm} / \mathrm{min}$, the normal pressures were $(100,200$ and 300) $\mathrm{kPa}$. The influence of gypsum content on the saturated shear strength parameters is given in Table 3 and illustrated in Fig. 8. It is obvious that the c' and $\varphi^{\prime}$ parameters decreased with increasing gypsum content in the clayey soil, whereas, the effective cohesion values were $(35.4,25.1 \mathrm{and} 20.0) \mathrm{kPa}$, whereas, the internal friction angle values were $\left(28.8^{\circ}, 25.8^{\circ}\right.$ and $\left.23.8^{\circ}\right)$ for $0 \%, 5 \%$ and $20 \%$ of gypsum content respectively. This reduction in the shear strength parameters can be attributed to the reduction in the cementing action between soil particles due to the dissolved of gypsum material when the soil specimen is fully saturated. These results agree with numerous researches such as Ahmad, Said, Najah [18].

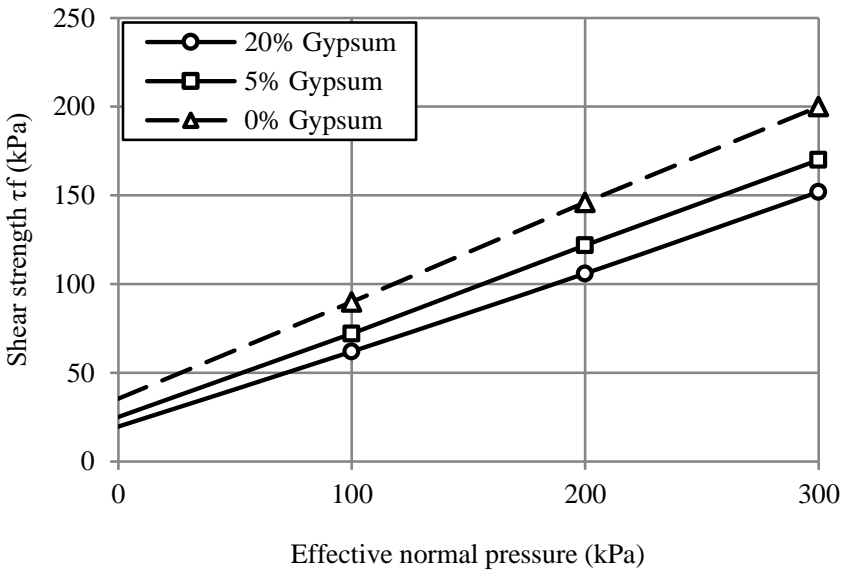

Fig. 8: Mohr Coulomb Failure Envelopes for the Saturated Soil.

\subsubsection{Prediction of shear strength envelopes of unsaturated soil}

To investigate the effect of gypsum content on the unsaturated shear strength of a clayey soil, SWRC variables exhibited in Table 4, and the saturated shear strength parameters acquired from direct shear test (exhibited in Table 1) have been used. Vanapalli's equation (equ. 4) was employed for this purpose. Fig. 9 exhibits the behavior of unsaturated shear strength with normal stress $\left(\sigma_{\mathrm{n}}=100\right) \mathrm{kPa}$. It is obvious that with increasing of soil suction, the $\mathrm{c}^{\prime}$ and $\varphi^{\prime}$ parameters are increased with a non linear behavior for the various gypsum contents, which are gradually reduced for a limited soil suction $(0-1000) \mathrm{kPa}$, this means that the value of unsaturated shear resistance $\left(\varphi^{\mathrm{b}}\right)$ is gradually reduced with increasing suction, it is generally not to exceed the effective internal friction angle $\left(\varphi^{\prime}\right)$. Also it can be seen that the unsaturated shear strength values decreased with increasing gypsum content in the clayey soil, where the values were (331, 283 and 270) $\mathrm{kPa}$ for $0 \%, 5 \%$ and $20 \%$ gypsum content respectively. This drop can be attributed to the reduction in cementing action between soil particles due to the dissolved of gypsum material when the soil specimen is partially saturated. 


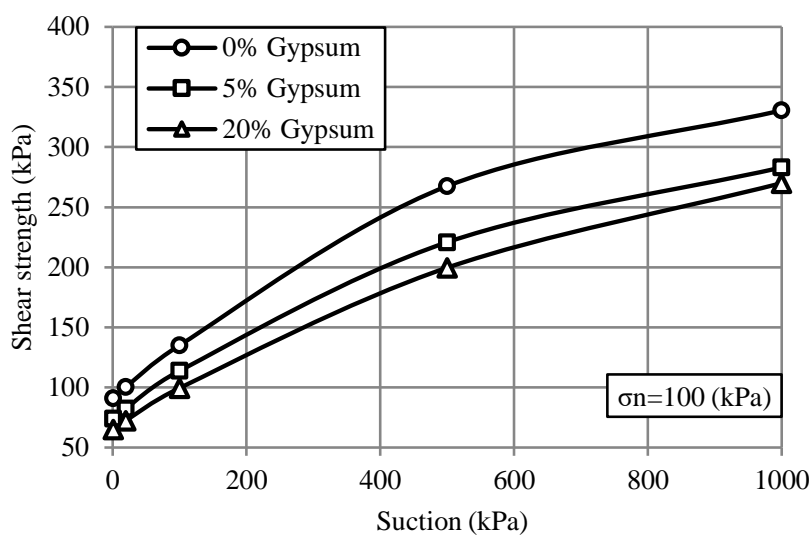

Fig. 9: Unsaturated Shear Strength at Normal Pressure (100) kPa versus Matric Soil Suction.

\section{Conclusions}

From the accomplished laboratory tests, and the predicted equations used in the research, the following observations may be concluded:

- The swelling potential decreased with increasing gypsum content, and the curve showed a distinct reduce variation initially, then, the curve decreased with a gentle slope.

- The storage capacity of water increased with increasing of gypsum content. This behavior is specified in the SWRC by increasing its variables representing by air entry and the residual moisture content.

- The saturated and unsaturated shear strength envelopes have decreased with increasing gypsum content in the clayey soil which is due to the reduction in cementing action through soil particles as a result of dissolve of gypsum material when the soil specimen is partially or fully saturated.

- The results of vapour diffusion indicate that the gypsum content could modify the microstructure in an unsaturated state and reduce the vapour diffusion of the soil. This is related to the role of gypsum particles which are very fine materials led to clog the pore spaces and formation of cementitious minerals.

\section{Acknowledgement}

The author would like to acknowledge the staff of Geotechnical laboratory, College of Engineering, Mosul University, Iraq, for their assistance and support during the experiments of this study.

\section{References}

[1] N. K. S. Al-Saoudi, A. N. Al-Khafaji, Challenging problems of gypseous soils in Iraq, Proceedings of the $18^{\text {th }}$ International Conference on Soil Mechanics and Geotechnical Engineering, Paris, 2013: 479-482.

[2] S. K. Vanapalli, D. G. Fredlund, D. E. Pufahl, A.W. Clifton, Model for the prediction of shear strength with respect to soil suction, Canadian Geotechnical Journal, 33 (3), 1996: 379-392. https://doi.org/10.1139/t96-060.

[3] D. G. Fredlund, R.M. the 1999 Hardy lecture, The implementation of unsaturated soil mechanics into geotechnical engineering, Canadian Geotechnical Journal, 37(5), 2000: 963-986. https://doi.org/10.1139/t00-026.

[4] D. Sheng, A. Zhou, D. G. Fredlund, Shear strength criteria for unsaturated soils, Geotechnical Geological Engineering, 29 (2), 2011: 145-159. https://doi.org/10.1007/s10706-009-9276-x.

[5] D. G. Fredlund, H. Rahardjo, 1993a, Soil mechanics for unsaturated soils, John Wiley \& Sons, New York. https://doi.org/10.1002/9780470172759.

[6] D. G. Fredlund, H. Rahardjo, 1993b, Equations for the soil-water characteristic curve, Canadian Geotechnical Journal, 31 (3), 1993: 521-532. https://doi.org/10.1139/t94-061.

[7] S. Nam, M. Gutierrez, P. Diplas, J. Petrie, A. Wayllace, N. Lu, J. J. Munoz, Comparison of testing techniques and models for establishing the SWRC of riverbank soils, Engineering Geology, 110, 2009: 1-10. https://doi.org/10.1016/j.enggeo.2009.09.003.

[8] S. K. Vanapalli, D. E. Pufahl, D. G. Fredlund, 1999a, Relationship between soil-water characteristic curves and the as-compacted water content versus soil for a clay till, In: Proceedings of the XI Pan-American conference on soil mechanics and foundation engineering, Brazil, 2, 1999: 991-998.

[9] S. K. Vanapalli, D. G. Fredlund, D. E. Pufahl, 1999b, The influence of soil structure and stress history on the soil water characteristic curve of a compacted till, Geotechnique, 51 (6), 1999: 573-576.

[10] ASTM Standard, 2003, American society for Testing and Material, Annual Book of ASTM standards.

[11] A.Aldaood, M. Bouasker, M. Al-Mukhtar, Soil-water characteristic curve of gypseous soil, Geotechnical and geological engineering, 33 (1), 2014 : 123135. https://doi.org/10.1007/s10706-014-9829-5.

[12] S. I. A. Khattab, M. N. J. Alzaidy, Effect of Anisotropy on Unsaturated Hydraulic Conductivity and SWCC of Clayey Soil, Al-Rafidain Engineering Journal, 21(1), 2013: 115-133. https://www.researchgate. net/publication/328610508.

[13] Q. Zhai, H.Rahardjo, Determination of soil-water characteristics curve variables, Computers and Geotechnics, 42, 2012: 37-43. https://doi.org/10.1016/j.compgeo.2011.11.010.

[14] K. Beck, M. Al-Mukhtar, O. Rozenbaumb, M. Rautureau, Characterization water transfer properties and deterioration in tuffeau building material in the Loire valley France, Building and Environment, 38 (9-10) 2003: 1151-1162. https://doi.org/10.1016/S0360-1323(03)00074-X.

[15] D. G. Fredlund, N. A. Morgernstern, R. A. Widger, The shear strength of unsaturated soils, Canadian Geotechnical Journal, 15, 1978: 313-321. https://www.researchgate.net/publication/292696798.https://doi.org/10.1139/t78-029.

[16] K. M. Gan, D. G. Fredlund, H. Rahardjio, Determination of the shear strength parameters of an unsaturated soil using the direct shear test, Canadian Geotechnical Journal, 25 (3), 1988: 500-510. https://doi.org/10.1139/t88-055.

[17] D. G.Fredlund, H. Rahardjo, M. D. Fredlund, Unsaturated Soil Mechanics in engineering practice, John Wiley \& Sons, 2012, Canada.https://doi.org/10.1002/9781118280492.

[18] F. Ahmad, M. A. Said, L. Najah, Effect of Leaching and Gypsum Content on Properties of Gypseous Soil, International Journal of Scientific and Research Publications, 2(9), 2012: 1-5.https://www.researchgate. net/publication/265693627. 